\title{
LICHENS FLORA OF PHULCHOKI (KATHMANDU)
}

\author{
A. Devkota
}

\section{ABSTRACT}

Study of lichens flora of Phulchoki showed that this area is rich in the lichen flora. A total of $\mathbf{2 5 0}$ different samples were collected from this area. The identification of collected specimens was done on basis of their morphological, anatomical and inimical studies. The lichens were collected from different altitudinal gradients extending from $1500-2700 \mathrm{~m}$. above sea level. The association of lichens with different substrata also studied. A total of 32 species of lichens were identified, which encompass 9 families and 10 genera. Among them family Parmeliaceae was largest.

Key words: Lichens, Morphology, Jhayaoo, Anatomy, Thin layer chromatography, Microcrystallography.

\section{INTRODUCTION}

In Nepali lichens are commonly known as Jhayaoo or Tare. They are dual organisms, i.e. they ae product of mutually benefited two organisms (Sharma, 1995). It is an association of a fungus (mycobiont) and an alga (phycobiont). Abbout 13,500 to 17,000 species of lichens extend from the tropics to the polar region. In Nepal, $471 \mathrm{spp}$. of lichens have been reported, of which 48 species are endemic. Baniya (1996) enumerated 99 species of lichens from Sikles and Shivapuri. Lichens are pioneer groups of organism that initiate vegetation in bare area. The components of lichen flora are governed by altitudinal variation. The growth forms of lichen also vary. Usually in Terai and Siwalik belt with alt. upto $1000 \mathrm{~m}$. the lichen flora consists of mainly crustose form. At higher alt. they remain either in foliose or fructicose form.

Very little work has been done in Nepal till now. Most of lichens of Nepal were recorded by foreigner as new record to science but not even a single type specimen kept in our herbaria. Most parts of Nepal remain lichenologically unexplored. It is felt that it is an important to make further exploration of lichen in order to make complete study on plant kingdom. So present study was undertaken with the objectives of collection of lichens and their identification.

\section{MATERIALS AND METHODOLOGY}

Materials were collected from Phulchoki (Ktm.) during $2^{\text {nd }}$ Jan. 2003 to $9^{\text {th }}$ Jan. 2003 , by sampling $10 \mathrm{~m} \times 10 \mathrm{~m}$ quadrat and $5 \mathrm{~m} \times 5 \mathrm{~m}$ sub-quadrat (Vetas, 1997). Lichens growing on different substrata were collected by standwise manner from $15000 \mathrm{~m}$ to $2700 \mathrm{~m}$ above sea level. All specimens were dried properly and herbaria were prepared according to method given by Nash et al. (1993).

\section{IDENTIFICATION}




\section{LICHENS FLORA OF PHULCHOKI (KATHMANDU)}

Lichens specimens collected during study period, were identified in the laboratory of the Central Department of Boatny, Tribhuvan University, Kirtipur. Each specimen was identified with the help of their morphology, anatomy, colour reaction, thin layer chromatography, microcrystallography and cross-checking of authentic samples deposited in Central Department of Botany.

To identify each genus and species, the Key to Macrolichens (Awasthi, 1988) and the Key to Microlichens (Awasthi, 1991) have been consulted.

\section{RESULT AND DISCUSSION}

A total of 32 species of lichens were identified in present study, which is given below. Their family, from and chemical constituents were also given.

1. Peltigera polydactyla (Neck.) Hoffm.,

\section{Peltigereaceae}

Thallus foliose, photobiont blue-green algae, muscicolous.

Chemical constituents - Tenuionin and Dolichorrhizin.

2. Parmelia cirrhata Fr. Syst. Orb. Veget., 1:383, 1825;

\section{Parmenaceae}

Thallus corticolous, lignicolous, foliose, grey to dark grey.

Chemical constituents - Altranorin, Salacinic acid and protolochesterinic acid.

3. Parmelia nepalensis Tayl., London J. Bot. 6:172, 1847; Parmenaceae

Thallus corticolous, foliose, grey to dark grey

Chemical constituents - Atranorin, Salacinic acid, protolichesterinic acid.

4. Parmelia nilgherrensis Nyl, Flora, 52:299, 1869, Parmeliaceae

Thallus corticolous, foliose, grey.

Chemical constituents - Atranorin, Alectoronic acid, $\alpha$-collatolic acid.

5. Parmelia reticulata Tayl, In Mack, Fl. Hibern, 2:148, 1836, Parmeliaceae

Thallus corticolous, Foliose, mineral grey to dark grey.

Chemical constituents- Atranorin, Salacinic acid.

6. Parmilia sancti-angelii Lynge, Ark.F.Bot. 13(13); 35,1914; Parmeliaceae

Thallus corticolous, foliose, grey to dark grey

Chemical constituents- Gyrophoric acid and Atranorin 
TRIBHUVAN UNIVERSITY JOURNAL, VOL. XXVI, NO. 1,

7. Parmelia tinctorum Nyl, Flora, 55:547, 1872; Parmeliaceae

Thallus conticolous, foliose, loosely to closely adnate to substracture glaucose grey.

Chemical constituents- Atranorin, Lecanoric acid.

8. Parmelia wallichiana Tayl. London J. Bot. 6:176, 1847; Parmeliaceae

Thallus corticolous, foliose, dark grey to whitish grey, rounded margin.

Chemical constituents- Atranorin and Salacinic acid.

9. Parmelia sulcata Tayl. In Mack; Flora Hibernica, 2:145, 1836; Parmeliaceae

Thallus corticolous, foliose, loosely attached to the substratum, rosette from, bluish grey.

Chemical constituents- Atranorin, Salacinic acid, Protocetraric acid.

10. Parmelia stuppea Tayl., Lond. J. Bot. Bot. 6:174, 1847; Parmeliaceae

Thallus corticolous, foliose, large, whitish grey, rotund.

Chemical constituents- Atranorin, Salacinic acid.

11. Parmelia flesilis Kurok., In Hara, The flora of Eastern Himalaya, 607, 1966; Parmeliaceae

Thallus corticolous, foliose, closely adnate to the substratum, margin creana whitisn grey.

Chemical constituents- Atranorin, protolichesterinic acid.

12. Parmelaria thomsonii (Stirt) Awas. Journ. Hattori Bot. Lab. No. 63:368370,1987; Par4meliaceae

Thallus corticolous, foliose, loosely attached to thesubstratum, ashy grey to grey.

Chemical constituents- Alectoronic acid and $\alpha$-collatolic acid.

13. Cladonia coniocraea (Flor.) Spreng. Syst. Veg. Linn., ed. 16, 4:277 1827; Cladoniaceae

Having primary squamules irregularly incised lobe, podetia cylindrical. Chemical constituents- Fumarprotocetratic acid.

14. Cladonic ramulosa (with.) Laundon, Lichenologist, 16(3):211-239, 1984 Cladoniaceae

Having persistent primary squamules, irregularly lobed, podetial cup simple.

Chemical constituents- Fumarprotocetraric acid. 


\section{LICHENS FLORA OF PHULCHOKI (KATHMANDU)}

15. Heterodermia diademata Tayl., J. Bot. London, 6:165, 1847; Physciaceae

Thallus loosely attached to the substratum. gravish white. lobes dichotomously to irregularly branced.

Chemical constituents- Atranorin, Zeorin.

16. Heterodermia dissecta (Kurok.) Awas. Geophy. 3(1):113-116,1973 Physciaceae

Thallus mineral greyish. closely appressed to the substratum. lobes dichotomously to irregularly brached.

Chemical constituents- Atranorin, Zeorin, Salacinic acid, Norstictic acid.

17. Heterodermia incana (Stirt) Awas geophy. 3(1):113-116, 1973; Physciaceae

Thallus whitish grey. attached centrallv to the subsstratum; foliose.

Chemical constituents- Atranorin, Zeorin.

18. Heterodemia leucomela (L.) Massal, Mem. Lich 35, 1853; Physciaceae

Thallus mineral grey. Loosely attached to the substratum, lobes dicholomously branched.

Chemical constituents- Atranorin, Zeorin, Salacinic acid.

19. Heterodermia pseudospeciosa (Kurok) W.culb.Brovologist 69:484, 1966; Physciaceae

Thallus mineral grey to grey, loosely attached to the substratum, growing in roucae parcnes.

Chemical constituents- Atranorin. Zeorin. Salacinic acid. Zeorin.

20. Heterodermi punctifera (Kurok.) Awas, Geophy: 3(1):114, 1973; Physciaceae

Thallus whitish grey, closely apprissd to the substratum, occurring in small orbicurar partcnes.

Chemical constituents- Atranorin. Zeorin. Norstictic acid.

21. Heterodermia speciosa Trev. Atti Soc. Ital. Sc. Nat. Milano xi:614, 1868: Physciaceae

Thallus whitish grey. closely appressed to the substratum.

Chemical constituents- Atranorin. Zeorin.

22. Usnea aciculifera Vain Bot. Mag. Tokyo 35:45 1921; Usneaceae 
TRIBHUVAN UNIVERSITY JOURNAL, VOL. XXVI, NO. 1,

Thallus corticolous, fructicose, decumbent to pendulous greenish yellow to brown.

Chemical constituents- Usnic acid, stictic acid.

23. Usnea orientalis Mot. Lich. Gen. Usnea stud. Monogr, Pars. syst. 547(1936-38); Usneaceae

Thallus corticolous, fructicose, erect upto $7 \mathrm{~cm}$, tall greenish grey.

Chemical constituents- Usnic acid. salacinic acid.

24. Usnea thomsoni; stirt. Scoot Nature 6:107; 1881; Usneaceae

Thallus corticolous. Erect 5-7 cm tall, dark brown to black.

Chemical constituents- Usnic acid and Stictic acid compiex.

25. Ramalina usnea (L.) Howe, Bryologist 17:81, 1914; Ramalinaceae

Thallus erect to subpendulous ribbon like thallus.

Chemical constituents- Sekikaic acid.

26. Ramalina sinensis Jatta, Nuov. Giorn. Bot. Ital. 9:462, 1902; Ramalinaceae

Thallus erect to subpendulous. Firmly attached to the substratum by narrow basal disc, pale - grey to greenish grey.

Chemical constituents- Usnic acid.

27. Stereocaulon coniophyllum Lamb. Journ Hattori Bot. Lab. Stereocaulaceae

Pseudopodetia sorediate, upto $5 \mathrm{~cm}$. Tall, robust, rigid.

Chemical constituents- Atranorin, lobaric acid.

28. Chrysothrix chlorina (Ach.) Laundon, Lichenologist, 13(2):106-110 mm. diam.

Thallus thick, yellow cu/rust, croticolous. Granules 0.1-0.2 mm. diam.

Chemical constituents- calyan and Vulpinic acid.

29. Leptogium delavayi Hue, Bull. Soc. Bot. France, 36:25, 1889; Collemataceae

Thallus corticolous, as well as muscicolous onbark and stond, foliose, dark grev to pate grey in dray.

30. Leptogium resupinas, Nyl, Annal, Soc. Nat. Bot. 15(4), 368, 1861; Collemataceae

Thallus foliose, upto $3 \mathrm{~cm}$. in size, ashy grey when dry, olive green when wet. 


\section{LICHENS FLORA OF PHULCHOKI (KATHMANDU)}

Chemical constituents- No lichen substances.

31. Leptogium indicum Awas, and P. Akhtar, Geophy: 8(2): 191-198, 1979; Collemataceae

Thallus foliose, $3-6 \mathrm{~cm}$ in size, light to dark lead grey when dry, olive green when wet.

Chemical constituents- No lichen substances.

32. Leptogium trichophiorwn Mull Arg. Flora 72; 505, 1889; Collemataceae

Thallus folise, upto $5 \mathrm{~cm}$ in size, loosely attached to the substratum grey brown to brown black when dry, dark olivaceus green when wet.

Chemical constituents- No lichen substance.

\section{CONCLUSION}

This paper has presented 9 families of lichens, they are under 10 genera and 32 species, among them genus Parmelia is largest one.

\section{WORKS CITED}

Awasthi, D.D. (1988). A Kev to Macrolichens of India Nepal. Journ. Hattori Bot. Lab. No. 65:207-302.

Awsthi, D.D. (1991). A Key to Microlichens in India, Nepal and Sri Lanka. Bibliotheca Lichenlogia 40: 1-330.

Baniya, C.B. (1996). The Floristic Composition of Lichens in Sikles (Kaski) and Shivapuri (Kathmandu) and their ecology. Thesis submitted for the partial fulfillment of the requirement of the master degree in Botany.

Nash, T.H.: Wetmore, C.M.: Anderson. W.: Brat. C.: Denison. C.: Eversman. S.: Murray, B.: Clari, L. (1993). Floristics, Lichens as Bioindicators of Air Quality U.S. Deparment of Agriculture, Fort Collins, Colorado, General, Technical Report. RM-224, 6-15.

Sharma, L.R. (1995) Enumeration of Lichens of Nepal, W.J.M. Verheught ed.: Ministry of forest and soil conservation and Department of National Parks and Wildlife conservation. Tech. Pub. No. 3. 1-111.

Vetaas, Ole R. (1997). Effect of Canopy disturbance on species richness in a Centre Himalayan Or forest. Plant Ecology. 132-38. 